\title{
Sakarya Üniversitesi Tıp Fakültesi Öğrencilerinde Uyku Kalitesi ve Etkileyen Faktörlerin Belirlenmesi
}

\author{
Determination of Sleep Quality and Affecting Factors in Students \\ of Sakarya University Medical Faculty
}
Nida Erdoğan', Meltem Pınar Karabel', Şeyda Tok', Derya Güzel'2, Hasan Çetin Ekerbiçer ${ }^{3}$

Sakarya Üniversitesi Tıp Fakültesi, Halk Sağlığı A.D., Sakarya

Sakarya Üniversitesi Tıp Fakültesi, Fizyoloji A.D., Sakarya

Yazışma Adresi / Correspondence:

Derya Güzel

Sakarya Üniversitesi, Tıp Fakültesi, Fizyoloji A.D, Sakarya / TÜRKiYE

T: +90 5541936443 E-mail: deryaguzel@sakarya.edu.tr

Geliş Tarihi / Received : 09.04.2018 Kabul Tarihi / Accepted : 02.05.2018

\begin{abstract}
Öz
Amaç Bu çalıșmada, tıp fakültesi öğrencilerinin uyku kalitesinin belirlenmesi ve yaşam kalitesinin uyku üzerine etkisinin araştrıılması amaçlanmıştır. Sakarya Tip Dergisi, 2018, 8(2):395-403 )

Gereç ve Kesitsel tipteki çalışmanın evrenini 2015-2016 eğitim ylında Sakarya Üniversitesi Tıp Fakültesi'nde okuyan 318 öğrenci oluşturmuştur.

Yöntem Katllımcılara Pittsburgh Uyku Kalitesi Ölçeği (PUKÖ) ve Kısa Form-36 Yașam Kalitesi Ölçeği (SF-36 YKÖ) uygulanmıștır. Ölçeklerin sosyodemografik özelliklerle ilişkileri de değerlendirilmiștir. Analizlerde tanımlayııı istatistikler, Kolmogorov-Smirnov normallik testi, Ki-kare Testi ve Spearman korelasyon katsayısı kullanılmıştır.

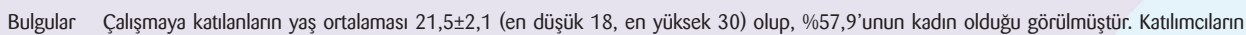
206’sı $(\% 64,8)$ evde kaldığını, 261'i (\%82,1) hiç sigara içmediğini, 260'ı (\%81,8) hiç alkol kullanmadığını, 158'i $(\% 49,7)$ kafeinli içecek-ilaç tükettiğini belirtmisțir. PUKÖ'ye göre çalșmaya katılanların \%64, 2'sinde uyku kalitesi kötü bulunmuștur. Uyku kalitesi puanı ile ders notu ortalaması arasında negatif yönlü zayıf bir ilişki bulunmuştur. Kafeinli içecek tüketenlerin uyku kalitesinin, kafeinli içecek tüketmeyenlere göre istatistiksel olarak daha kötü olduğu görülmüştür. YKÖ alt başlıklarına göre çalışmaya katılanların aldıkları puan ortalamalarının en yüksek fiziksel fonksiyon alanında (ortalama 88,4; en yüksek 100; en düșük 0), en düșük duygusal rol fonksiyon alanında (ortalama 45,9; en yüksek 100; en düşük 0) olduğu görülmüştür. Uyku kalitesi ölçeği puanı ile yașam kalitesinin tüm alt başlıkları arasında negatif yönlü orta ya da zayıf ilişki olduğu görülmüştür. Sınıf ile genel sağlık algısı, sosyal fonksiyon ve duygusal rol fonksiyon arasında pozitif yönlü zayıf ilişki saptanmıștir.

Sonuç Çalışmamızda uyku kalitesi seviyesinin düşük olduğu saptanmıștır. Tıp fakültesi öğrencilerinin yaşam kalitesi açısından duygusal ve sosyal alanda daha eksik oldukları görülmüștür. Eğitim sürecinde öğrencilere hizmet veren psikolojik danıșma ve rehberlik alanlarının olması, sosyal aktivite düzeyini artırıcı faaliyetlerin düzenlenmesi faydalı olabilir.

Anahtar Tıp öğrencileri; Pittsburgh Uyku Kalitesi Ölçeği; Kısa Form-36 Yaşam Kalitesi Ölçeğ

Kelimeler
\end{abstract}

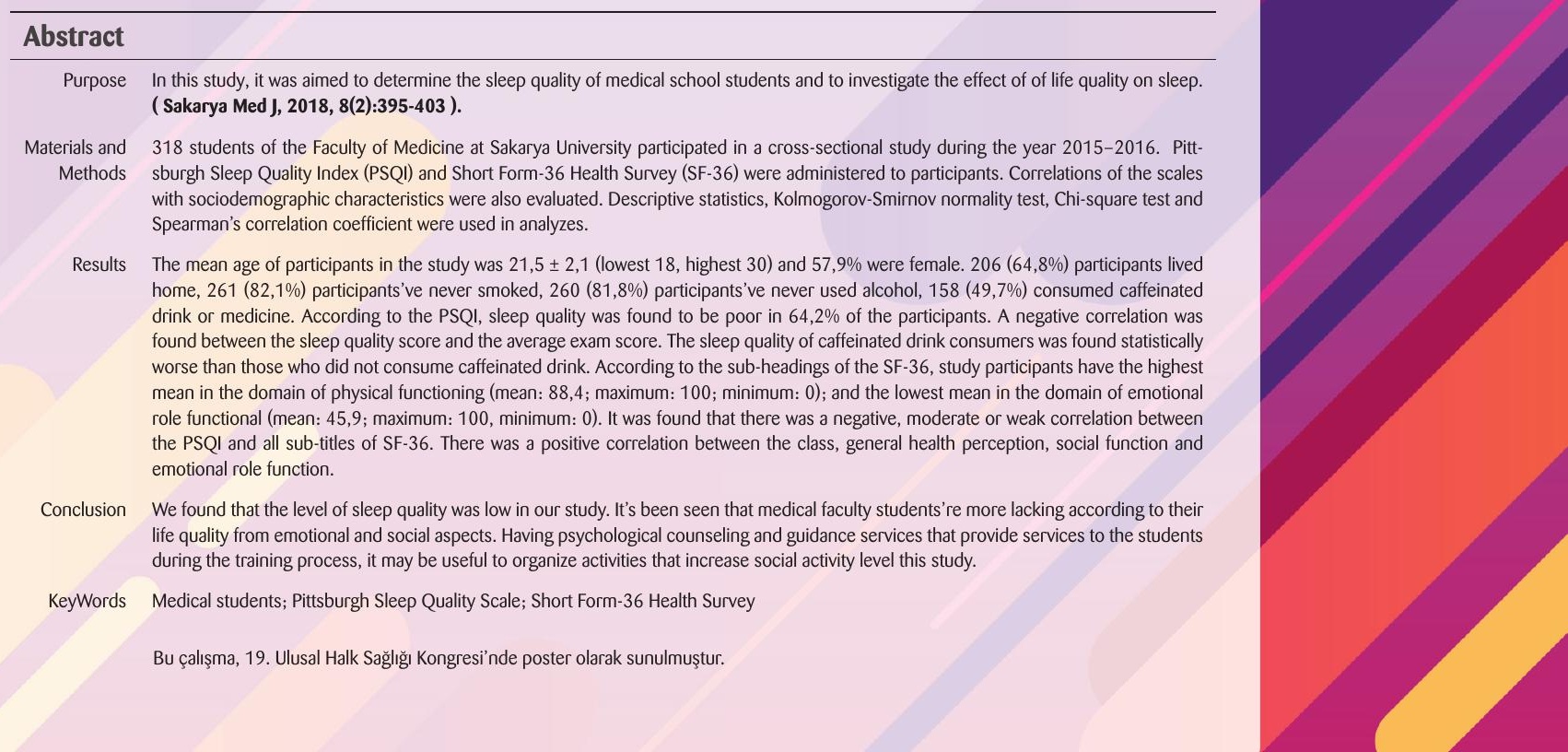


Sakarya TIp Dergisi 2018;8(2):395-403

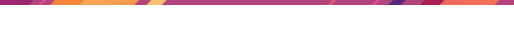

Uyku eski çağlardan bu yana keşfedilmek istenen bir süreç olmuştur. 1957'de Kleitman ve Dement, insanın uyku döngüsünün tekrarlayan evrelerden oluştuğunu göstermiştir. ${ }^{2}$ Uykuda birbirini periyodik olarak izleyen dönemler; REM (Rapid Eye Movement) ve Non-REM dönemleridir.1 REM uykusunun keşfi ile uykuda beynin aktif olmadığı düşüncesinin aksine beynin uykuda da aktif bir konumda olduğu görülmüştür. ${ }^{2}$

Uyku Tıbbı Amerikan Akademisi'nin ve Uyku Araştırmaları Topluluğu'nun uzlaşı bildirisine göre 18-60 yaş arası bireylerin düzenli olarak geceleri en az 7 saat uyuması sağlığı en iyi şekilde desteklemektedir. ${ }^{3} 1920$ 'de Nathaniel Kleitman'ın insanlarda uyku yoksunluğu ile ilgili gerçekleştirdiği deneylerde 60 saat uykusuz kalan bireylerin olabilecekleri en fazla bitkinlik halinde olduklarını ve bu sürenin üzerindeki uykusuzluklarda bitkinlik durumunda fazla değişim olmadığı gösterilmiştir. ${ }^{2}$ Uyku bozukluklarına bağlı kötü uyku kalitesi ve uykuda azalma modern topluluklarda yaygın hale gelmiştir. işs ve aile nedeniyle düzenlenen yeni yaşam değişiklikleri, fiziksel ve psikolojik sorunlar, internet ve televizyona bağlı sosyal değişiklikler nedeniyle uykunun kısıtlanması, metabolik süreci etkileyen endemik bir hal almışırı. ${ }^{4}$ Uyku kalitesi ve okul performansı üzerine yapılmış bir meta-analizde çocuk ve ergenlerde, kötü uyku kalitesinin kötü okul performansına sebep olduğu görülmüştür. ${ }^{5}$ Lübnan'da üniversite öğrencileri arasında Pittsburgh Uyku Kalitesi Ölçeği (PUKÖ) kullanılarak yapılan bir çalışmada öğrencilerin uyku kalitesi çoğunlukta kötü olup bu durumun öğrencilerin sosyal alanlardaki eylemleriyle ilişkisi olduğu saptanmıştır. ${ }^{6}$ Türkiye'de PUKÖ kullanılarak yapılmış bir çalışmada bir tıp fakültesindeki 4.-5.-6. sınıf öğrencilerin yarııına yakınında uyku kalitesinin kötü olduğu görülmüştür. ${ }^{7}$ Benzer şekilde yapılmış başka bir çalışmada lise öğrencilerinde uyku kalitesinin yarısından fazlasında kötü olduğu görülmüştür. ${ }^{8}$ Görüldüğü gibi öğrenciler arasında kötü uyku kalitesi giderek yaygınlaşmaktadır.

Kötü uyku kalitesi beraberinde sağlık problemlerine ve öğrencilerin okulda başarısız olmasına sebep olmaktadır. ${ }^{9}$ Bu çalışmada, Sakarya Üniversitesi tıp fakültesi öğrencilerinin uyku kalitesini belirlemek ve bunu etkileyebilecek yaşam kalitesi, sosyodemografik değişkenler, sosyal davranışlar gibi faktörlerle ilişkisini araştırmak amaçlanmışır.

\section{Gereç Ve Yöntem}

Kesitsel tipte planlanan bu çalışmanın evrenini Sakarya Üniversitesi Tıp Fakültesi'nde okuyan tüm öğrenciler oluşturdu. Evrenin tamamına ulaşılması hedeflendiği için örneklem seçilmedi. Evreni oluşturan Sakarya Üniversitesi Tıp Fakültesi'nde 2015-2016 ders yilında okuyan öğrencilerin toplamı 370 idi. Gönüllülük esasına dayalı olan çalışmaya, 52 kişi katılmak istemediği için veya çalışma sırasında okulda bulunmadığı için katılamadı. Toplam 318 kişiye $(\% 85,9)$ ulaşııldı. Çalışmaya, Sakarya Üniversitesi Girişimsel Olmayan Araştırmalar Etik Kurulu’nun 22/12/2015 tarih 71522473/050.01.04/158 sayılı izni ile başlandı. 
Veri toplama aracı olarak literatür taranarak araştırmacılar tarafından hazırlanan standart bir anket formu kullanıldı. Anket formunun ilk bölümünde kişilerin yaş, cinsiyet, yaşadığı yer, işte çalışma durumu, ekonomik durum algısı, sigara içme durumu, alkol kullanımı, kitap okuma alışkanlığı, geçmiş dönem ders notu ortalaması, bilgisayar-televizyon başında geçen günlük ortalama saat, gün içinde uyuklama alışkanlığı, kafein tüketimi ile ilgili sorular yer almaktaydı. íkinci bölüm Pittsburgh Uyku Kalitesi Ölçeği ve son olarak üçüncü bölüm Kısa Form-36 Yaşam Kalitesi Ölçeği'nden oluşmaktaydı. Anket formları ders öncesi öğrencilere dağıtıldı ve kendileri doldurduktan sonra toplandı.

Pittsburgh Uyku Kalitesi Ölçeği (PUKÖ), Buysse ve arkadaşları tarafından 1989 yılında geliştirilmiştir.10 1996 yılında Ağargün ve arkadaşları tarafından Türkçe’ye uyarlanan ölçek 24 sorudan oluşmaktadır. ${ }^{11}$ Bu sorulardan 19'u kendini değerlendirme olup 5’i bireyin eşi veya arkadaşı tarafından cevaplanmaktadır. Ölçeğin toplam ve bileşen puanlarının hesaplanmasında eşe veya arkadaşa sorulan sorular puanlamaya alınmamaktadır. Bireyin kendini değerlendirme soruları uyku kalitesi, uyku süresi, uyku latensi, alışılmış uyku etkinliği, uyku bozukluğu, uyku ilacı kullanımı, gündüz işlev bozukluğu ile ilgili etmenleri değerlendirmektedir. PUKÖ’de toplam puanın 5 ve üzerinde olmasının kötü uyku kalitesini gösterdiği belirtilmektedir. ${ }^{12}$

Kısa Form-36 (SF-36) Yaşam Kalitesi Ölçeği, Ware ve Sherbourne tarafından 1992 yılında geliştirilmiş, yaşam kalitesini ölçmede yaygın olarak kullanılan bir ölçektir. ${ }^{13}$ Türkçe geçerlilik ve güvenilirlik çalışması 1999 yılında Koçyiğit ve arkadaşları tarafından yapılmıştır. ${ }^{14}$ Ölçek; fiziksel aktivite yapabilme performansını gösteren fiziksel fonksiyon, fiziksel ve duygusal sorunlara bağlı iş ve diğer günlük aktivitelerini yapabilmesini gösteren rol kısıtlamaları, sosyal aktivitelerini yapabilme performansını gösteren sosyal fonksiyon, kişinin sinirli veya mutlu veya sakin hissetme durumunu gösteren mental sağlık, kişinin enerji dolu ve canlı hissetme durumunu gösteren vitalite (enerji), ağrı hissetmesi veya ağrıya bağlı kısıtılık durumunu sorgulayan ağrı ve kişinin sağığıyla ilgili algısını sorgulayan genel sağlık algısı gibi sağlığın sekiz boyutunu 36 madde ile incelemektedir. Ölçeğin toplam puanı yoktur; yalnızca sekiz alt boyutun toplam puanı hesaplanır. Alanlardan alınan puanın yüksek olması olumlu, düşük olması olumsuz durumu gösterir. ${ }^{13}$ Türkiye'de yapılan çalışma sonucunda Türk toplumunun standartları elde edilmiştir. ${ }^{15}$ PUKÖ ile SF-36 yaşam kalitesi ölçeği arasında ortak soru bulunmamaktadır.

Bağımlı değişkeni uyku kalitesi olan araştırmanın bağımsız değişkenleri sosyodemografik veriler ve SF-36 Yaşam kalitesi alt boyutları idi.

Verilerin çözümlenmesinde tanımlayıcı istatistikler (frekans, ortalama, standart sapma, ortanca, 1. ve 3. çeyreklikler, en düşük ve en yüksek değerler), Kolmogorov-Smirnov normallik testi, önemlilik testlerinden Ki-kare Testi ve Spearman korelasyon katsayısı kullanıldı. Çalışmada istatistiksel önemlilik düzeyi $p \leq 0.05$ olarak kabul edildi. . Tüm analizler SPSS 20.0 bilgisayar programı yardımıyla yapılmıştır.

\section{Bulgular}

Çalışmaya 184’ü kız $(\% 57,9)$, 134’ü erkek $(\% 42,9)$ olmak üzere toplam 318 öğrenci katıldı. Katılımcıların yaş ortalamasının 21, $\pm 2,0$ Standart Sapma (SS) (en düşük 18, en yüksek 30) olduğu

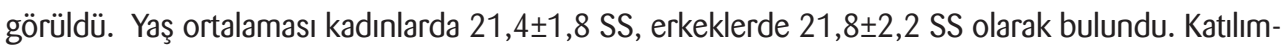
cıların 206’sı $(\% 64,8)$ evde kaldığını, 261’i $(\% 82,1)$ hiç sigara içmediğini, 260’ı $(\% 81,8)$ hiç alkol
Sakarya Tip Dergisi

2018;8(2):395-403

ERDOĞAN ve Ark.

Sakarya Üniversitesi Tip Fakültesi Öğrencilerinde Uyku

Kalitesi Ve Etkileyen Faktörlerin Belirlenmes 


\begin{tabular}{|c|c|c|c|c|c|c|c|c|}
\hline & $\begin{array}{l}\text { Sayı } \\
\text { (n) }\end{array}$ & Ort $\pm S S^{*}$ & Ortanca & EBD* & EKD* & 1.çeyrek & 3.çeyrek & $\begin{array}{c}\text { Türk } \\
\text { toplumu } \\
\text { standartları** }^{* *}\end{array}$ \\
\hline Fiziksel fonksiyon & 312 & $88,4 \pm 14,8$ & 95,0 & 100,0 & 0,0 & 85,0 & 100,0 & 100 \\
\hline $\begin{array}{l}\text { Fiziksel rol } \\
\text { fonksiyon }\end{array}$ & 311 & $70,2 \pm 38,1$ & 100,0 & 100,0 & 0,0 & 25,0 & 100,0 & 100 \\
\hline Ağrı & 313 & $67,8 \pm 18,0$ & 72,0 & 90,0 & 0,0 & 52,0 & 84,0 & 100 \\
\hline Genel sağlık algısı & 310 & $64,8 \pm 17,3$ & 67,0 & 100,0 & 10,0 & 52,0 & 77,0 & 72 \\
\hline Enerji (Zindelik) & 313 & $53,1 \pm 19,7$ & 55,0 & 100,0 & 0,0 & 40,0 & 65,0 & 70 \\
\hline Sosyal fonksiyon & 311 & $69,3 \pm 24,0$ & 75,0 & 100,0 & 12,5 & 50,0 & 87,5 & 100 \\
\hline $\begin{array}{l}\text { Duygusal rol } \\
\text { fonksiyon }\end{array}$ & 310 & $45,9 \pm 44,7$ & 33,3 & 100,0 & 0,0 & 0,0 & 100,0 & 100 \\
\hline Mental sağlık & 313 & $65,0 \pm 15,4$ & 68,0 & 100,0 & 24,0 & 56,0 & 76,0 & 76 \\
\hline Sağlıkta değişikli & 314 & $49,1 \pm 22,7$ & 50,0 & 100,0 & 0,0 & 25,0 & 75,0 & \\
\hline
\end{tabular}

Uyku kalitesi ile ders dışı kitap-dergi okuma, sigara içme durumu, alkol kullanımı arasında istatistiksel olarak anlamlı bir fark olmadığı görülmüştür $(p>0,05)$. Kafein içeren içecek kullanma durumuna göre uyku kalitesi karşılaştıııınca istatistiksel olarak anlamlı bir fark vardı. Kafeinli içecek kullananların \% 75,5'inde uyku kalitesi kötü saptanırken, kullanmayanların \%62,8'inde uyku kalitesinin kötü olduğu saptandı $(p=0,018)$ (Tablo-3).

\begin{tabular}{|c|c|c|c|c|c|c|}
\hline \multicolumn{7}{|c|}{ Tablo-3: Katılımcıların bazı özelliklerinin uyku kalitesi ile ilişkisi* } \\
\hline & & & \multicolumn{2}{|c|}{ Uyku kalitesi } & $P$ değeri & Ki-kare değeri \\
\hline & & & İyi & Kötü & \multirow{5}{*}{0,846} & \multirow{5}{*}{0,038} \\
\hline \multirow{4}{*}{ 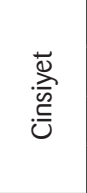 } & Kadın & $\mathrm{N}$ & 54 & 116 & & \\
\hline & & $\%$ & 31,8 & 68,2 & & \\
\hline & Erkek & $\mathrm{N}$ & 39 & 88 & & \\
\hline & & $\%$ & 30,7 & 69,3 & & \\
\hline \multirow{4}{*}{ 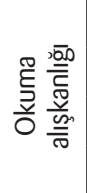 } & Haftada en az 2-3 gün & $\mathrm{N}$ & 54 & 121 & \multirow{4}{*}{0,802} & \multirow{4}{*}{0,063} \\
\hline & & $\%$ & 30,9 & 69,1 & & \\
\hline & Haftada bir veya daha az gün & $\mathrm{N}$ & 39 & 82 & & \\
\hline & & $\%$ & 32,2 & 67,8 & & \\
\hline \multirow{4}{*}{ 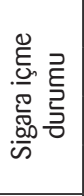 } & Hiç içmemiş & $\mathrm{N}$ & 82 & 164 & \multirow{4}{*}{0,099} & \multirow{4}{*}{2,718} \\
\hline & & $\%$ & 33,3 & 66,7 & & \\
\hline & Halen içiyor/ Iç̧iyormuş bırakmış & $\mathrm{N}$ & 11 & 40 & & \\
\hline & & $\%$ & 21,6 & 78,4 & & \\
\hline \multirow{4}{*}{$\begin{array}{l}\bar{E} \\
\overline{\bar{E}} \\
\overline{\overline{\bar{v}}} \\
\overline{\bar{\sigma}} \\
\overline{\underline{z}}\end{array}$} & Hiç kullanmamış & $\mathrm{N}$ & 79 & 166 & \multirow{4}{*}{0,385} & \multirow{4}{*}{0,755} \\
\hline & & $\%$ & 32,2 & 67,8 & & \\
\hline & Halen kullanıyor/ Kullanıyormuş bırakmış & $\mathrm{N}$ & 13 & 37 & & \\
\hline & & $\%$ & 26,0 & 74,0 & & \\
\hline \multirow{4}{*}{ 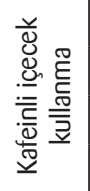 } & Evet & $\mathrm{N}$ & 36 & 111 & \multirow{4}{*}{$0,018 \#$} & \multirow{4}{*}{5,567} \\
\hline & & $\%$ & 24,5 & 75,5 & & \\
\hline & Hayır & $\mathrm{N}$ & 54 & 91 & & \\
\hline & & $\%$ & 37,2 & 62,8 & & \\
\hline $\begin{array}{l}\text { *Yüzde } \\
\# p \text { değ }\end{array}$ & $\begin{array}{l}\text { iatıra aittir. N: Sayı. } \\
r i \leq 0,05\end{array}$ & & & & & \\
\hline
\end{tabular}

Sakarya Tip Dergisi

2018;8(2):395-403

ERDOĞAN ve Ark.
Sakarya Üniversitesi Tip Fakültesi Öğrencilerinde Uyku Kalitesi Ve Etkileyen Faktörlerin Belirlenmesi 
Sakarya TIp Dergisi 2018;8(2):395-403
Uyku kalitesi ile ders notu ortalaması arasında negatif yönlü zayıf bir ilişki bulundu. Televizyon-bilgisayar başında geçen süre ile uyku kalitesi arasında istatistiksel olarak anlamlı bir ilişki saptanmadı (sırasıyla r:-0,197 ve $\rho=0,005 ;$ r: 0,040 ve $\rho=0,493$ ). Uyku kalitesi ölçeği puanı ile yaşam kalitesinin tüm alt başıkları arasında negatif yönlü orta ya da zayıf ilişki olduğu görüldü. Bunun yanı sıra duygusal rol fonksiyonu alanıyla televizyon-bilgisayar başında geçen süre arasında ve yaş ile sosyal fonksiyon arasında pozitif yönlü zayıf ilişki bulundu. Sınıf ile genel sağılık algısı, sosyal fonksiyon ve duygusal rol fonksiyon arasında pozitif yönlü zayıf ilişki saptandı (Tablo-4).

\begin{tabular}{|c|c|c|c|c|c|c|c|c|c|c|c|}
\hline \multicolumn{12}{|c|}{$\begin{array}{l}\text { Tablo-4: Katılımcıların yaşı, okuduğu sınıf, not ortalaması, SF-36 yaşam kalitesi alt boyutları ve uyku } \\
\text { kalitesi arasındaki korelasyon ilişkisi }\end{array}$} \\
\hline & & $\begin{array}{l}\text { Uyku } \\
\text { ÖP }\end{array}$ & FF & FRF & Ağrı & GS & Enerji & SF & DRF & MS & SD \\
\hline \multirow{3}{*}{$\begin{array}{l}: 0 \\
\text { : } \\
\text { 产 }\end{array}$} & $\mathrm{R}$ & 1,000 &,- 148 & -,202 & -209 &,- 282 & -341 & -309 &,- 345 & 293,- & 137, - \\
\hline & $P$ & & ,011 & 000 & ,000 &, 000 & ,000 & ,000 & 000 & ,000, & 018 \\
\hline & $\mathrm{N}$ & 297 & 296 & 295 & 295 & 294 & 295 & 295 & 294 & 295 & 297 \\
\hline \multirow{3}{*}{$\stackrel{\infty}{\stackrel{\infty}{\infty}}$} & $\mathrm{R}$ & -061 & 083 & 114 & ,068 & ,076 & ,021 & 123, & 101 & ,027 & ,004 \\
\hline & $\mathrm{P}$ & 294 & 144 & ,044 & ,229 & 183 & ,713 & ,030, & 076, & 638, & 943 \\
\hline & $\mathrm{N}$ & 296 & 311 & 310 & 312 & 309 & 312 & 310 & 309 & 312 & 313 \\
\hline \multirow{3}{*}{$\begin{array}{l}\text { 㰴 } \\
\text { क }\end{array}$} & $R$ & -093 & ,091 & 144 & ,010 & ,121 & ,039 & , 146 & 140 & ,083 & -025 \\
\hline & $\mathrm{P}$ & 108 & 108 & ,011 & ,862 & ,034 & ,496 & 010 & 014 & , 145 & 663 \\
\hline & $\mathrm{N}$ & 297 & 312 & 311 & 313 & 310 & 313 & 311 & 310 & 313 & 314 \\
\hline \multirow{3}{*}{$\stackrel{\leftarrow}{2}$} & $\mathrm{R}$ & -197 & -072 & ,072 & -011 & 041 & ,030 & 050 & 037 & 078 & 010 \\
\hline & $\mathrm{P}$ & ,005 & 299 & 299 & 870 & ,557 & 665 & 471 & ,594 & ,262 & 886 \\
\hline & $\mathrm{N}$ & 198 & 209 & 209 & 210 & 208 & 210 & 209 & 209 & 210 & 209 \\
\hline \multirow{3}{*}{$\begin{array}{l}z^{\prime} \overline{\aleph^{\prime}} \\
u^{\prime}:\end{array}$} & $\mathrm{R}$ & ,040 & ,003, & -,006 & ,039, & 093 & ,066 & ,067 & ,114 & ,035, &,- 011 \\
\hline & $\mathrm{P}$ & 493 & ,952 & 921 & ,498 & 104 & 249 & 242 & 046 & ,537 & 850 \\
\hline & & 295 & 310 & 309 & 311 & 308 & 311 & 309 & 308 & 311 & 312 \\
\hline \multicolumn{12}{|c|}{ 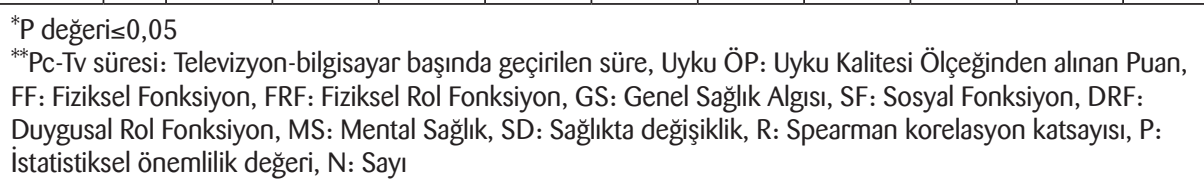 } \\
\hline
\end{tabular}

\section{Tartışma}

Çalışmamıza toplam 318 kişi katılmış olup, katılımcıların toplam PUKÖ puanı ortalaması 5,7士2,3 idi. Çalışmaya katılanların uyku kalitesinin \%64,2'sinde kötü olduğu görüldü. İzmir’de bir üniversitenin hemşirelik, tıp ve eczacılık fakültelerinde eğitim alan 300 öğrenci ile yürütülmüş bir çalışmada öğrencilerin PUKÖ puan ortalaması 6,1 $\pm 1,9$; uyku kalitesi kötü olanların oranı $\% 59$ bulunmuştur. ${ }^{16}$ Tayvan'da 2360 öğrencinin katıldığı bir çalışmada \%54,7'sinde uyku kalitesi kötü saptanmıştır. ${ }^{17}$ Düzce Üniversitesi'nde tıp öğrencilerine yapılmış bir çalışmada PUKÖ ve uyku bozukluğuna etki eden faktörler sorgulanmıştır. Düzce'de yapılan çalışmada PUKÖ'den aldıkları ortalama puan 5,2 \pm

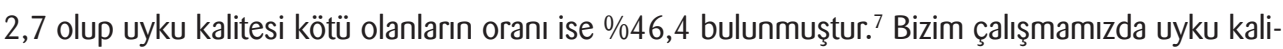
tesi kötü olanların daha yüksek oranda olduğu görülmüştür. Uyku kalitesini kimi çalışmalar altı puan ve üzerinde kötü olarak değerlendirirken ${ }^{7}$ kimi çalışmalar beş puan ve üzerini kötü olarak değerlendirmektedir. ${ }^{16,17}$ Bizim çalışmamızda Türk Toraks Derneği Obstrüktif Uyku Apne Sendromu Tanı Ve Tedavi Uzlaşı Raporu'nu temel alarak beş puan ve üzerini kötü uyku kalitesi olarak değerlendirildi. ${ }^{12}$ Yapılan çalışmalarda uyku kalitesini altı ve üzerinde puanı olanlarda kötü olarak değerlendirdikleri için kötü uyku kalitesi oranları daha düşük çıkmış olabilir. 
Yaptığımız çalışmada kafeinli içecek kullananlarda uyku kalitesinin kullanmayanlara göre istatistiksel olarak anlamlı şekilde daha kötü olduğu görülmüştür. İzmir'de yapılmış çalışmada kafeinli içecek alma durumuna göre elde edilen uyku kalitesi puan ortalamaları arasında da anlamlı bir fark bulunmuştur. ${ }^{16}$ Tayvan'da yapılmış çalışmada haftada üç kereden fazla çay içmek kötü uyku kalitesi açııından risk teşkil etmektedir ancak kahve içenlerde böyle bir risk bulunmamıştır. ${ }^{17}$ Uyku yoksunluğuna bağı azalan bilişsel fonksiyonları artırmak için kafein tüketiminin faydası vardır. Bu nedenle uykusuz kalan bireyler uyuyarak bilişsel fonksiyonlarını düzenlemek yerine kafeinli ürün tüketerek uykusuzluk sorununu daha da artırmaktadır.18 Bu durumda kahve ve çay içmeye bağı uyku kalitesinin düşük olması beklenebilir. Ancak Tayvan'da yapılmış çalışmadaki gibi ayrıntılı olarak tüketim miktarını sorgulamak kafein tüketiminin uyku üzerindeki etkisi hakkında daha farklı sonuçlar verebilir.

Bizim çalışmamızda sigara içme durumu ve alkol kullanımı ile uyku kalitesi arasında istatistiksel olarak anlamlı bir fark bulunmamıştır. Tayvan'da yapılan bir çalışmada sigara içme ile uyku kalitesi arasında anlamlı bir fark tespit edilemese de bununla birlikte alkol kullananlarda uyku kalitesi anlamIı olarak daha kötü bulunmuştur. ${ }^{17}$ İzmir'de yapılmış çalışmada sigara içmenin uyku kalitesi puanını etkilemediği görülürken alkol kullanımının uyku kalitesini kötü etkilediği görülmüştür.16 Yapılan çalışmalar arasında sigara içmenin uyku kalitesini etkilemesi yönünden fark bulunmamasının sebebi bizim çalışmamızda da olduğu gibi günlük içilen sigara sayısının sorgulanması yerine sadece sigara içme durumunun sorgulanması olabilir. Bunun yanı sıra sigara ve alkolün kişide çeşitli uyku sorunları yarattığı bilinmektedir. ${ }^{19,20}$ Bu nedenle sigara içen ve alkol kullananlarda uyku kalitesinde farklılık beklenebilir. Bizim çalışmamızda alkol kullanan sayısı az olduğundan farklılık bulunamamış olabilir. Ayrıca çalışmanın günlük içilen sigara sayısı sorularak tekrarlanması durumunda sonuçta farklılık olabilir.

Almanya'da bir tıp fakültesinde yapılmış çalışmada sınavdan önceki dönemde iyi uyku kalitesinin sınav performansını olumlu yönde etkilediği görülmüştür. ${ }^{9}$ Bu durum uyku kalitesinin kötü olmasına bağlı sınav başarısının düşük olmasını düşündürebilir. Ancak bizim çalışmamızda sınav not ortalaması ile uyku kalitesi arasında negatif yönlü zayıf bir ilişki olduğu görülmüştür. Bu durum sınavlarda başarılı olmak için daha çok uykusuz kaldıklarını ve sınav stresine bağı daha çok uyku sorunu çektiklerini düşündürebilir.

Çalışmamızda diğer çalışmalardan farklı olarak uyku kalitesi ile yaşam kalitesi değerlendirilmiştir. Uyku kalitesi ile yaşam kalitesinin alt başııkları arasında negatif yönlü orta ya da zayıf ilişki olduğu görülmüştür. Bu sonuç beklenen bir durum değildir. Çünkü uyku kalitesinin bozulmasına bağı yaşam kalitesinin olumsuz etkilenmesinin yanı sıra yaşam kalitesinin bozulmasına bağlı olarak da uyku kalitesi kötüleşebilir. Bu konuda ikisini karşılaştıran çalışmalarda hastalıklara özgü değerlendirme yapıldığından, bizim çalışmamızla bu durumu karşılaştırabileceğimiz bir örnek yoktur. Bununla beraber uyku kalitesi bozuldukça artan ders başarısı ve başarıya endeksli yaşam kalitesi algısı artıyor olabilir. Yaşam kalitesinin Türk toplumu standartlarına göre dağıımını karşısıştıracak olursak çalışmamızda fiziksel fonksiyon ve fiziksel rol fonksiyon alt boyutları dışındaki tüm alt boyutlarda ortanca değer Türk toplumu standartlarına göre oldukça düşük kalmaktadır. Demiral ve arkadaşlarının yaptığı çalışmada belirlenen norm değerler 18 yaş ve üzeri toplumu kapsayacak şekilde yapılmıştır. ${ }^{15}$ Bizim çalışmamızda ise katılımcılar genç erişkin nüfus ile sınırıdır. Bu nedenle arada farklılıklar olabilir. En büyük fark sırasıyla duygusal rol fonksiyon, ağrı, sosyal fonksiyon ve enerji alt boyutlarında görülmektedir. Çalışmamızda öğrencinin bulunduğu dönem yilı arttıkça genel sağık
Sakarya Tıp Dergisi

2018;8(2):395-403

ERDOĞAN ve Ark.
Sakarya Üniversitesi Tip Fakültesi Öğrencilerinde Uyku Kalitesi Ve Etkileyen Faktörlerin Belirlenmesi 
Sakarya TIp Dergisi 2018;8(2):395-403

algısı, sosyal fonksiyon ve duygusal rol fonksiyon alanlarında artış görülmektedir. Bu durum tıp fakültesine yeni başlayanların duygusal problemlerinin daha çok olduğunu ve sosyal aktivitelerden uzaklaştığını düşündürebilir.

Çalışmanın kısıtllı̆̆ı olarak evrenin tamamına ulaşılamadığı, bunun sebebi olarak da ilk üç sınıfta öğrencilerin devamsızlık hakkını kullanma eğilimi görülmektedir. Geçmiş yıl not ortalamalarının sorulduğu sorunun değerlendirilmesinde 1.sınıflar dâhil edilmedi. Televizyon- bilgisayar başında geçen süre günlük ortalama kaç saat şeklinde sorulmuş olup kişilerin belirttiği en yüksek rakam esas alındı. Katılımcılara sigara içme ve alkol kullanma durumu soruldu ancak günlük kullanılan miktarlar sorgulanmadı.

\section{Sonuç}

Özet olarak bizim çalışmamızda uyku kalitesi diğer çalışmalara göre daha kötü bulunmuştur. Bu durum çalışmalar arasındaki farklı sınır (cut-off) değerlerinden kaynaklanmış olabilmekle birlikte öğrencilerimizin uyku sorunu yaşadığı açıkça görülmektedir. Öğrencilerin kafein tüketimlerini sınırlamak faydalı olabilir. Uyku kalitesi ölçeği ile yaşam kalitesi arasında ters bir ilişki olduğu görülmüştür. Bu durumun yaşam kalitesi algısının, azalan uyku kalitesi ile ilişkili artan başarıya bağlı olduğu düşünülmüştür. Kişiler başarı elde edebilmek için uykularını bozacak şekilde muhtaç bırakılmamalıdır, başarı elde edebilmek uğruna uykudan feragat edilmemeli, gerekirse eğitim sisteminde değişikliklere gidilmelidir. Uyku kalitesini geliştirebilmek için yaşam kalitesini de iyileştirmek gerekir. Ayrıca tıp fakültesi öğrencilerinin yaşam kalitesi açııından duygusal ve sosyal alanda daha eksik oldukları görülmüştür. Eğitim sürecinde öğrencilere hizmet veren psikolojik danışma ve rehberlik alanlarının olması, sosyal aktivite düzeyini artııcı spor, tiyatro, sinema gibi faaliyetlerin düzenlenmesi ve öğrencilerin yoğun eğitim sürecinde bu tür faaliyetlere katılımı teşvik edilmelidir. 
1. Karadağ M. Uyku bozuklukları sınfflaması (ICSD-2). Turkiye Klinikleri Archives of Lung, 2007, 8: 88-91.

2. Gökçay B, Arda B. Sleep and Sleep Medicine in the Light of Medical History-Tıp Tarihi Açııından Uyku ve Uyku Araștırmaları. Mersin Üniversitesi Tıp Fakültesi Lokman Hekim Tıp Tarihi ve Folklorik Tıp Dergisi, 2013 3: 70-78

3. Recommended amount of sleep for a healthy adult: a joint consensus statement of the American Academy of Sleep Medicine and Sleep Research Society. Sleep, 2015, 38: 843-844.

4. Hirotsu C, Tufik S, Andersen ML. Interactions between sleep, stress, and metabolism: from physiological to pathological conditions. Sleep Science, 2015, 8: 143-152.

5. Dewald JF, Meijer AM, Oort F), Kerkhof GA, Bögels SM. The influence of sleep quality, sleep duration and sleepiness on school performance in children and adolescents: a meta-analytic review. Sleep medicine reviews, 2010, 14: 179-189.

6. Kabrita CS, Hajjar-Muça TA, Duffy JF. Predictors of poor sleep quality among Lebanese university students: association between evening typology, lifestyle behaviors, and sleep habits. Nature and science of sleep, 2014, 6: 11 .

7. MAYDA AS, KASAP H, YILDIRIM C, YILMAZ M, DERDIYOK C, ERTAN D, ERTEN R, GÜL AH, Gökçe G, Mehmet K. 4-5-6. sınıf tıp fakültesi öğrencilerinde uyku bozukluğu sıklığı. Düzce Üniversitesi Sağlık Bilimler Enstitüsü Dergisi, 2012, 2: 8-11.

8. ŞENOL V, SOYUER F, AKÇA RP, ARGÜN M. Adolesanlarda uyku kalitesi ve etkileyen faktörler. Kocatepe Tip Dergisi, 2012, 13.

9. Ahrberg K, Dresler M, Niedermaier S, Steiger A, Genzel L. The interaction between sleep quality and academic performance. Journal of psychiatric research, 2012, 46: 1618-1622.
10. Buysse DJ, Reynolds CF, Monk TH, Berman SR, Kupfer DJ. The Pittsburgh Sleep Quality Index: a new instrument for psychiatric practice and rese arch. Psychiatry research, 1989, 28: 193-213.

11. Ağargün MY, Kara H, Anlar Ö. The validity and reliability of the Pittsburgh Sleep Quality Index. Turk Psikiyatri Derg, 1996, 7: 107-15.

12. Derneği UÇTTT. obstrüktif uyku apne sendromu tanı ve tedavi uzlaşı raporu. Türk Toraks Dergisi, 2012, 13: 59-63.

13. Montazeri A, Goshtasebi A, Vahdaninia M, Gandek B. The Short Form Health Survey (SF-36): translation and validation study of the Iranian version. Quality of life research, 2005, 14: 875-882.

14. Kocyigit H. Kisa Form-36 (KF-36) nin Turkce versiyonunun guvenirlig vegecerliligi.[Validity and reliability of Turkish version of SF-36]. J Drug Ther, 1999, 12: 102-106.

15. Demiral Y, Ergor G, Unal B, Semin S, Akvardar Y, Kivırcık B, Alptekin K. Normative data and discriminative properties of short form 36 (SF-36) in Turkish urban population. BMC public health, 2006, 6: 247.

16. Aysan E, Karaköse S, Zaybak A, GÜNAY ISMAiLOĞLU E. Üniversite öğrencilerinde uyku kalitesi ve etkileyen faktörler. 2014.

17. Cheng SH, Shih C-C, Lee IH, Hou Y-W, Chen KC, Chen K-T, Yang YK, Yang YC. A study on the sleep quality of incoming university students. Psychiatry research, 2012, 197: 270-274.

18. Council NR. Caffeine for the sustainment of mental task performance: Formulations for military operations. Washington, DC: National Academy Press, 2001, 6: 104-168.

19. Thakkar MM, Sharma R, Sahota P. Alcohol disrupts sleep homeostasis. Alcohol, 2015, 49: 299-310

20.James JE, Kristjánsson ÁL, Sigfúsdóttir ID. Adolescent substance use, sle$\mathrm{ep}$, and academic achievement: evidence of harm due to caffeine. Journa of adolescence, 2011, 34: 665-673.
Sakarya Tıp Dergisi

2018;8(2):395-403

ERDOĞAN ve Ark.

Sakarya Üniversitesi Tip Fakültesi Öğrencilerinde Uyku

Kalitesi Ve Etkileyen Faktörlerin Belirlenmesi 